\title{
Особенности начальной стадии гетероэпитаксии слоев кремния на германии при их выращивании из гидридов кремния
}

\author{
Орлов Л.К. ${ }^{2}$, Ивина Н.Л. ${ }^{1}$ \\ ${ }^{1}$ ИФМ РАН, 603950, Нижний Новгород, ГСП-105 \\ ${ }^{2}$ РАНХиГС, 603950, Нижний Новгород пр. Гагарина, 46
}

DOI 10.34077/Semicond2019-105

Среди обсуждаемых гетерокомпозиций одними из наиболее привлекательных являются псевдоморфные $\mathrm{Si} / \mathrm{Ge}$ гетерокомпозиции с толщинами слоев $\mathrm{Si}$ и $\mathrm{Ge}$ от нескольких монослоев до нескольких нанометров. Исследования особенностей применения атомно-слоевой эпитаксии для выращивания планарных $\mathrm{Ge} / \mathrm{Si}$ структур показали, однако, срыв механизма слоевого роста пленок уже на толщинах порядка нескольких монослоев и формирование на поверхности массива островков. Поэтому внимание исследователей было сосредоточено в основном на характеристиках гетероструктур с двумерными массивами чаще всего германиевых, изредка кремниевых, квантовых точек, выращиваемых из атомарных пучков в высоком вакууме. Методы химической эпитаксии применительно к системе $\mathrm{Ge} / \mathrm{Si}$ использовались, главным образом, с целью поиска условий выращивания плоскослоистых напряженных гетероструктур для транзисторной электроники. Предотвращение срыва механизма слоевого роста и выращивание как тонких слоев $\mathrm{Ge}$ на $\mathrm{Si}$, так и тонких слоев $\mathrm{Si}$ на Ge в установках с гидридными источниками обеспечивалось применением низких $\left(<450^{\circ} \mathrm{C}\right)$ температур в присутствие поверхностного водорода. В связи с исследованиями механизма роста квантовых точек Ge на поверхности Si в предыдущие годы активно изучалась начальная стадия гетероэпитаксии напряженных «сжатием в плоскости» слоев Ge на $\mathrm{Si}$. Для ряда приложений интерес представляют также характеристики начальной стадии роста напряженных «растяжением в плоскости» слоев $\mathrm{Si}$ на Ge. В связи с этим значительный интерес вызывает характер зависимости скорости осаждения из гидридов пленок $\mathrm{Si}$ и Ge не только от температуры ростового процесса, но и от толщины наращиваемого слоя. Изучение морфологии поверхности и кристаллической структуры $\mathrm{Si}(\mathrm{Ge})$ пленок разной толщины на начальной стадии гетероэпитаксии позволяет не только проследить возможную смену механизма роста и изучить особенности 2D-3D морфологического перехода, но и проанализировать влияние каталитических свойств подстилающего $\mathrm{Ge}(\mathrm{Si})$ слоя на процессы поверхностного распада молекул гидридов, участвующих в эпитаксиальном процессе.

Нами проанализированы зависимости скорости роста слоев $\mathrm{Si}(\mathrm{Ge})$, осаждаемых гидридным методом на $\mathrm{Ge}(\mathrm{Si})$ поверхность, от их толщины на начальной стадии гетероэпитаксии. Для слоев $\mathrm{Si}$, растущих на Ge при повышенном давлении водорода, продемонстрирован слоевой характер роста $\mathrm{Si}$ слоев при повышенных (до $650^{\circ} \mathrm{C}$ ) температурах. Обнаружено влияние на скорость роста пленки $\mathrm{Si}$ подложки Ge в пределах 10 наращиваемых монослоев Si. На основании данных технологических экспериментов проведен расчет кинетических коэффициентов, ответственных за скорости протекания основных физико-химических процессов, связанных с взаимодействием молекулярных пучков гидридов с ростовой поверхностью. Анализ вероятности захвата и скоростей пиролиза адсорбируемых молекул гидрида $\mathrm{Si}(\mathrm{Ge})$ на поверхностях $\mathrm{Ge}(\mathrm{Si})$ показал зависимость их поведения от толщины наращиваемого слоя. Из сопоставления полученных при росте слоя $\mathrm{Si}$ на Ge результатов обнаружено, что поверхность Ge по отношению к молекулам силана обладает более высокими адсорбционной и каталитической способностями, нежели поверхность Si. По отношению к молекулам гидридов $\mathrm{Ge}$ более высокими адсорбционными и каталитическими характеристиками соответственно обладает поверхность $\mathrm{Si}[1]$.

Работа выполнена при поддержке гранта РФФИ № 18-42-520062.

[1] Л.К. Орлов, Н.Л. Ивина, В.А. Боженкин. // ФТП. 2019. Т.53. № 7. С.995. 